\title{
PENGARUH FAKTOR -FAKTOR KARAKTERISTIK BUDAYA ORGANISASI TERHADAP KINERJA PEGAWAI DINAS PEMBERDAYAAN MASYARAKAT DAN DESA KABUPATEN ASAHAN
}

\author{
${ }^{1}$ Ery Dermawan, ${ }^{2}$ Ulfah Nuri Daualy, ${ }^{3}$ Rusdi Sibagariang, ${ }^{4}$ Edison Rambe, ${ }^{5}$ Arfan Sutono \\ $1,2,3,4,5$ Universitas Islam Sumatera Utara \\ Iery.darmawan@gmail.com, ${ }^{2}$ ulfa.nuri@gmail.com, ${ }^{3}$ rusdi.sibagariang@gmail.com, ${ }^{4}$ Edison.rambe@gmail.com, \\ 5 arfan.sutono@gmail.com
}

\begin{abstract}
This research discusses about the influences of innovation, detail attention and output orientation on employees' performance at Community and Village Empowerment of Asahan Regency. The aim of this research is to analyse influences of innovation, detail attention and output orientation both partially and simultaneously on employees' performance at the office. This is a quantitative research with total sampling technique. Sample is 45 employees. Results show that each independent variable; innovation, detail attention and output orientation, partially influences employees' performance positively and significantly. Innovation has tcount value 3,795 and level of significance 0.000, detail attention has 4,188 and 0.010, and output orientation has 5,435 and 0.000. Simultaneously, innovation, detail attention and output orientation have significant and positive influences on employees' performance at Community and Village Empowerment of Asahan Regency with Fcount value 45,204 and level of significance 0.000.
\end{abstract}

Keywords: innovation, detail attention, output orientation, performance, employee.

ABSTRAK : Penelitian ini membahas tentang bagaimana pengaruh inovasi, perhatian secara rinci dan orientasi hasil terhadap kinerja pegawai Dinas Pemberdayaan Masyarakat dan Desa Kabupaten Asahan. Penelitian ini bertujuan untuk menguji pengaruh inovasi, perhatian secara rinci dan orientasi hasil baik secara parsial maupun simultan terhadap kinerja pegawai Dinas Pemberdayaan Masyarakat dan Desa Kabupaten Asahan. Penelitian ini merupakan penelitian kuantitatif dengan teknik penarikan sampel yang digunakan adalah total sampling. Sampel sebanyak 45 orang pegawai. Hasil penelitian menunjukkan bahwa variabel inovasimemiliki nilai thitung sebesar 3,795 dan signifikansi 0,000, variabel perhatian secara rinci memiliki nilai thitung sebesar 4,188 dan signifikansi 0,000, dan orientasi hasil memiliki nilai thitung sebesar 5,435 dan signifikansi 0,000. Dengan demikian dapat dikatakan bahwa secara parsial masing-masing dari variabel inovasi, perhatian secara rinci dan orientasi hasil berpengaruh positif dan signifikan terhadap kinerja pegawai. Secara simultan, inovasi, perhatian secara rinci dan orientasi hasil tersebut juga berpengaruh positif dan signifikan terhadap kinerja pegawai Dinas Pemberdayaan Masyarakat dan Desa Kabupaten Asahan dengan nilai Fhitung sebesar 45,204 dan signifikansi 0,000.

Kata Kunci: inovasi, perhatian secara rinci, orientasi hasil, kinerja, pegawai

\section{Pendahuluan}

Seiring dengan berkembangnya zaman menuju arah yang lebih modern, perlu disadari pola fikir masyarakat juga semakin berkembang, salah satunya di bidang ekonomi. Perkembangan di bidang ekonomi semakin hari semakin ketatdalam persaingan dan mengharuskan perusahaan untuk mengembangkan segala potensi yang ada di dalam perusahaannya untuk terus berinovasi, terutama di bidangsumber daya manusia.
Potensi setiap sumber daya manusiayang ada dalam perusahaan harus dapat dimanfaatkan dengan sebaik-baiknya sehingga mampu memberikan outputoptimal.

Oleh karena itu, perusahaan juga dituntut untuk mampu mengidentifikasi hal-hal apa saja yang menjadi kendala atau permasalahan di dalam menjalankan kegiatan dan aktivitas ekonomi, termasuk masalah Kinerja pegawainya dimana setiap perusahaan memiliki 
budaya organisasi yang berbeda dan karakteristik pegawai yang berbeda pula.

Banyak faktor yang mendorong dan mempengaruhi sumberdaya manusia yang dimiliki perusahaan agar bergerak kearah positif. Perlakuan terhadap tenaga manusia tentunya berbeda dengan perlakuan terhadap faktor produksi yang lainnya, karena tenaga manusia memiliki karakteristik yang berbedabeda. Di sinilah tantangan bagi perusahaan untuk mengatur berbagai macam kekhususan yang dimiliki tenaga kerja yaitu pegawai guna mencapai tujuan perusahaan.

Budayaorganisasi adalah salah satu faktor yang mempengaruhi tendensi anggota untuk tetap bersama organisasi dan menjaga loyalitasnya.

Menurut Tika (2008:65) budaya organisasia dalah nilai dan praktik yang memiliki bersama diseluruh kelompok dalam satu perusahaan, sekurang- kurangnya dalam manajemen senior dan definisi antara budaya organisasi dan budaya perusahaan saling terkait karena keduaduanya memiliki kesamaan, meskipun dalam budaya organisasi terdapat hal-hal khusus sebagai gaya manajemen, sistem manajemen, dan sebagainya, namun semuanya tetap dalamrangkaian budaya organisasi. Budaya organisasi membentuk nilai dan standar yang menuntun perilaku organisasi, kondisi tersebut dapat menentukan arah dari seluruh tujuan perusahaan. Budaya organisasi merupakan nilainilai bersama dan kepercayaan yang diberikan oleh anggota pada organisasi yang kemudian menghasilkan aturan-aturan berperilaku dalam keseharian berorganisasi.

Suatu budaya organisasi yang kuat memperlihatkan kesepakatan yang tinggi di kalangan anggota yang dipegang teguh dan disepakati bersama. Kuat lemahnya budaya suatu organisasi sangat bergantung pada bagaimana anggota mengaplikasikannya pada kehidupan berorganisasi dalam perusahaan. Budaya organisasi yang baik diharapkan mampu memberikan kenyamanan anggota atau pegawai dalam bekerja dan mampu memberikan peningkatan kinerja yang optimal, sehingga pegawai mampu memenuhi ekspetasi yang diharapkan oleh perusahaan.

Selain budaya organisasi perusahaan juga harus mampu menganalisis dan menyelesaikan permasalahan yang kecil namun menentukan tujuan perusahaan akan berjalan dengan baik atau tidak, hal kecil itu yaitu karakteristik individu dari pegawai-pegawai sendiri. karakteristik pegawai yang berbeda-beda akan menjadi suatu permasalahan yang fatal apabila perusahaan, khususnya manajer tidak mampu membawa perbedaan tersebut menjadi satu visi dan misi demi tujuan perusahaan itu sendiri. Perbedaan yang tercermin itu diharapkan memberikan keunikan dan keragaman dalamsuatu perusahaan dalam meningkatkan kinerja pegawai maupun memberikan inovasiinovasi, ataupun ide-ide gagasan yang mampu memberikan keuntungan dan kemajuan perusahaan. Namun, karena perbedaan karakteristik itu permasalahan antar pegawai tidak dapat dipungkiri akan terjadi, seperti hal persaingan dalam bekerja ataupun hal-hal lain yang mampu membuat penurunan kinerja pegawai dan menjadikan suasana dalam perusahaan menjadi tidak kondusif, disini perusahaan diharuskan mampu menengahi dan meminimalisir hal-hal tersebut.

Perusahaan diharapkan peka dan mampu memberikan motivasi-motivasi yang mampu mengkondusifkan suasana dalam perusahaan itu sendiri. Sama halnya dengan budaya organisasi dan karakteristik individu yang berbeda-beda, motivasi dari perusahaan juga merupakan suatu hal yang sangat perlu diperhatikan dalam meningkatkan kinerja pegawai sesuai tujuan perusahaan. Motivasi menurut Mangkunegaran, AA. Anwar Prabu. (2005: 23) adalah kesediaan untuk mengeluarkan tingkat upaya yang tinggi kearah tujuanorganisasi, yang dikondisikan oleh kemampuan itu untukmemenuhi sesuatu kebutuhan individu.

Motivasi merupakanfaktor yang mampu memberikan pengaruh yang besar bagipegawai, baik motivasi dari perusahaan ataupun motivasiyang datang dari diri sendiri. Motivasi yang tepat akanmenentukan tingkatan prestasi pegawai, yang pada akhirnya akan mempengaruhi efektifitas pencapaian tujuan organisasi. Motivasi merupakan hal yang mampu membuat seseorangmelakukan sesuatu hal dengan baik dari sebelumnya, disiniperusahaan, khususnya manajer diharapkan mampu menggunakan faktor-faktor motivasi secara tepat dalam rangka mengarahkan pegawai agar bisa bekerja dengan lebih efektif dan produktif bagi organisasi kerjanya.

Dari semua faktor-faktor diatas, perusahaan meengharapkan pegawai mampu meningkatkan kinerjanya sesuai dengan ekspetasi perusahaan, atau bahkan mampu melebihi apa 
yangdiharapakan. Kinerja menurut Wibowo (2010:22) adalah hasil kerja pegawai dilihat dari aspek kualitas, kuantitas, waktu kerja sama untuk mencapai tujuan yang sudah ditetapkan oleh perusahaan. Sehingga dalam aplikasinya peningkatan kinerja pegawai merupakan hal yang sangat penting dalam kemajuan pegawai itu sendiri dan perusahaan. Yang pada akhirnya perusahaan menginginkan mampu bersaing dan mampu mengembangkan usaha dan mendapatkan profitabilitas melalui segala kebijakan dan ketentuan yang diberikan kepada pegawainya. Hal ini juga tidak lepas apayang dilakukan dan diberikan Dinas Pemberdayaan Masyarakat dan Desa Kabupaten Asahan kepada pegawai-pegawainya.

Dinas Pemberdayaan Masyarakat dan Desa Kabupaten Asahan merupakan instansi Negara. Perbedaan kebudayaan atau kebiasaan pegawai dari tempat asal masing-masing pasti menjadi masalah yang tidak dapat dihindari, belum lagi karakteristik individu tiap pegawai yang beragam. Oleh karena itu Dinas Pemberdayaan Masyarakat dan Desa Kabupaten Asahan. dituntut untuk mampu menciptakan suatu budaya organisasi yang mampu menyatukan dan memberikan kenyamanan pegawai dalam bekerja, serta tanggap dalam menangani perbedaan karakteristik pegawainya. Kebijakan-kebijakan yang tepat sangat diperlukan Dinas Pemberdayaan Masyarakat dan Desa Kabupaten Asahan untuk memotivasi dan meningkatkan kinerja pegawai. Budaya organisasi seperti apakah yang harus digunakan dalam menyikapi perbedaan karakteristik individu, sekaligus mampu memotivasi dan meningkatkan kinerja pegawai menjadi masalah paling utama. Dari latar belakang inilah penulis ingin mengetahui apakah budaya organisasi dan karakteristik individu tiap pegawai mampu mempengaruhimotivasi serta kinerja dari pegawai itu sendiri.

Sebuah organisasi mempunyai budaya masing-masing. Ini menjadi salah satu pembeda antara satu organisasi dengan organisasi lainnya. Budaya organisasi mencerminkan nilai \pm nilai sebuah perusahaan dan dapat membawa dampak positif bagi karyawannya dan memiliki dampak positif secara internal, budaya perusahaan yang baik dan mendorong semangat bekerja dapat membantu sebuah bisnis memenangkan persaingan.

Jika sudah terdapat sistem nilai yang sudah menjadi budaya perusahaan yang kuat dan dijalankan dapat menumbuhkan rasa kepemilikan, membangkitkan sernangat kerja, dan dapat mendapatkan sukses bagi perusahaan. Budaya yang dijalankan oleh semua anggota perusahaan secara konsisten dapat menciptakan hidup beroganisasi yang tebuka, karyawan bebas mengungkapkan pikiran, perasaan dan berpartisipasi dalam proses pengambilan keputusan. Kinerja mempunyai arti penting bagi karyawan, adanya penilaian kinerja berarti karyawan mendapat perhatian dari atasan, disamping itu akan menambah gairah dan emangat kerja karyawan. Kinerja yang dimiliki oleh karyawan pada hakikatnya merupakan suatu akibat dari persyaratan kerja yang harus dipenuhi oleh karyawan. Karyawan akan bersedia bekerja dengan penuh semangat apabila merasa kebutuhan baik fisik dan non fisik terpenuhi.

Kesadaran para karyawan ataupun pimpinannya akan pengaruh positif budaya organisasi terhadap kinerja karyawan akan memberikan motivasi yang kuat untuk mempertahankan, memelihara, dan mengembangankan budaya organisasi yang dimiliki, sehingga merupakan daya dorong yang kuat untuk kemajuan organisasi. Sebagaimana temuan Kotter dan James (1997), menunjukkan bahwa organisasi berprestasi karena ditopang budaya organisasi yang kuat.

Mangkunegara (2005) menyatakan bahwa budaya organisasi adalah seperangkat asumsi atau sistem keyakinan, nilai-nilai, dan norma yang dikembangkan dalam organisasi yang dijadikan pedoman tingkah laku bagi anggotaanggotanya untuk mengatasi masalah adaptasi eksternal dan internal. Dengan demikian dapat disimpulkan bahwa budaya organisasi merupakan pola keyakinan dan nilai-nilai organisasi yang diyakini dan dijiwai oleh seluruh anggotanya dalam melakukan pekerjaan sebagai cara yang tepat untuk memahami, memikirkan, dan merasakan terhadap masalah-masalah terkait, sehingga akan menjadi sebuah nilai atau aturan turun temurun di dalam organisasi tersebut.

Kinerja karyawan adalah yang mempengaruhi seberapa banyak mereka memberi kontribusi kepada organisasi. Perbaikan kinerja baik untuk individu maupun kelompok menjadi pusat perhatian dalam upaya meningkatkan kinerja organisasi, seperti yang diungkapkan oleh Mathis \& Jackson (2002). Faktor-faktor yang mempengaruhi kinerja individu tenaga kerja, yaitu: kemampuan mereka, motivasi, dukungan yang diterima, 
keberadaan pekerjaan yang mereka lakukan, dan hubungan mereka dengan organisasi.

Menurut Hasibuan (2014), kinerja karyawan dapat dikatakan baik atau dapat dinilai dari beberapa hal, yaitu: kesetiaan, prestasi kerja, kedisiplinan, kreatifitas, kerjasama, kecakapan, dan tanggung jawab. Menurut Robbins (2002) menyatakan bahwa ada tujuh karakteristik budaya organisasi yang dapat mempengaruhi kinerja karyawan yaitu: Inovasi, Perhatian secara Rinci dan Orientasi Hasil kemantapan.

\subsection{Batasan Masalah}

Batasan masalah dimaksudkan untuk membatasi ruang lingkup kajian dalam penelitian. Agar permasalahan yang dikaji terarah maka permasalahan dibatasi dengan hanya mengkaji tentang pengaruh Inovasi, Perhatian secara Rinci dan Orientasi Hasil para pegawai yang dipengaruhi oleh faktor-faktor seperti motivasi, lingkungan kerja dan tanggung jawab sebagai realisasi kedisplinan yang secara bersama-sama memberikan kontribusi ataupun tidak terhadap produktivitas kerja Pegawai Dinas Pemberdayaan Masyarakat dan Desa Kabupaten Asahan.

\subsection{Rumusan Masalah}

Berdasarkan latar belakang masalah dan identifikasi permasalah sebagaimana tersebut di atas, rumusan masalah dalam penelitian ini adalah:

a. Bagaimana pengaruh Inovasi terhadap kinerja Pegawai Dinas Pemberdayaan Masyarakat dan Desa Kabupaten Asahan?

b. Bagaimana pengaruh Perhatian secara Rinci terhadap Individu terhadap kinerja Pegawai Dinas Pemberdayaan Masyarakat dan Desa Kabupaten Asahan?

c. Bagaimana pengaruh Orientasi Hasil terhadap kinerja Pegawai Dinas Pemberdayaan Masyarakat dan Desa Kabupaten Asahan?

d. Bagaimana pengaruh Inovasi, Perhatian secara Rinci dan Orientasi Hasil Pegawai Dinas Pemberdayaan Masyarakat dan Desa Kabupaten Asahan?

\subsection{Tujuan Penelitian.}

Berdasarkan rumusan masalah penelitian sebagaimana diuraikan di atas, maka tujuan yang hendak dicapai dalam penelitian ini yaitu:

a. Menganalisis pengaruh Inovasi terhadap kinerja Pegawai Dinas Pemberdayaan Masyarakat dan Desa Kabupaten Asahan b. Menganalisis pengaruh Perhatian secara Rinci terhadap Individu terhadap kinerja Pegawai Dinas Pemberdayaan Masyarakat dan Desa Kabupaten Asahan.

c. Menganalisis pengaruh Orientasi Hasil terhadap kinerja Pegawai Dinas Pemberdayaan Masyarakat dan Desa Kabupaten Asahan.

d. Menganalisis pengaruh Inovasi, Perhatian secara Rinci dan Orientasi Hasil terhadap kinerja Pegawai Dinas Pemberdayaan Masyarakat dan Desa Kabupaten Asahan.

\subsection{Hipotesis}

Hipotesis pada penelitian ini dapat dirumuskan sebagai berikut:

a. Ada pengaruh yang ditampilkan Inovasi organisasional terhadap kinerja pegawai Dinas Pemberdayaan Masyarakat dan Desa Kabupaten Asahan

b. Ada pengaruh yang ditampilkan Perhatican secara Rinci terhadap kinerja kerja pegawai Dinas Pemberdayaan Masyarakat dan Desa Kabupaten Asahan.

c. Ada pengaruh yang ditampilkan Orientasi Hasil terhadap kinerja pegawai Dinas Pemberdayaan Masyarakat dan Desa Kabupaten Asahan.

d. Ada pengaruh yang ditampilkan Inovasi, Perhatican secara Rinci, dan Orientasi Hasil secara bersama-sama terhadap kinerja pegawai Dinas Pemberdayaan Masyarakat dan Desa Kabupaten Asahan.

\section{Metode Penelitian \\ 2.1. Populasi}

Populasi merupakan suatu kesuluruhan objek yang dapat berupa manusia, benda, makhluk hidup lainnya, gejala atau peristiwa yang memiliki karakteristik dan tempat yang sama dalam waktu tertentu. Menurut Sugiyono (2005), populasi adalah wilayah generalisasi yang terdiri atas objek/subjek yang mempunyai kualitas dan karakteristik tertentu yang ditetapkan oleh peneliti untuk dipelajari kemudian ditarik kesimpulannya. Populasi dalam penelitian ini adalah seluruh pegawai di Dinas Dinas Pemberdayaan Masyarakat dan Desa Kabupaten Asahan sebanyak 47 orang. 
Tabel 1. Kerangka Populasi Berdasarkan Jabatan 2021

\begin{tabular}{|l|l|c|}
\hline No & \multicolumn{1}{|c|}{ Jabatan } & Jlh Populasi \\
\hline 1. & Kepala Dinas & 1 \\
\hline 2. & Sekretaris & 1 \\
\hline 3. & Kepala Bidang & 3 \\
\hline 4. & Kepala Seksi & 9 \\
\hline 5. & Kepala Sub. Bagian & 2 \\
\hline 6. & Staf/Jabatan Fungsional & 15 \\
\hline 7. & Tenaga SP3/ Tenaga Sukarela & 16 \\
\hline \multicolumn{2}{|c|}{ Jumlah } & $\mathbf{4 7}$ \\
\hline
\end{tabular}

Sumber: Dinas Pemberdayaan Masyarakat dan Desa Kabupaten Asahan., 2021

\subsection{Sampel}

Sampel atau dalam Bahasa Inggris sample adalah bagian dari populasi yang ingin diteliti; dipandang sebagai suatu pendugaan terhadap populasi, bukan bukan populasi itu sendiri. Sampel dianggap sebagai perwakilan dari populasi yang hasilnya mewakili keseluruhan gejala yang diamati. Ukuran dan keragaman sampel menjadi penentu baik atau tidaknya sampel yang diambil.

Sampel dapat dipahami sebagai kumpulan data yang lebih kecil yang dipilih dari populasi yang lebih besar dengan menggunakan metode seleksi yang telah ditentukan. Elemenelemen ini dikenal sebagai titik sampel, unit sampling atau pengamatan. Membuat sampel adalah metode yang efisien dalam melakukan penelitian seperti dalam kebanyakan kasus, tidak mungkin atau sangat mahal dan memakan waktu untuk meneliti seluruh populasi dan karenanya meneliti sampel memberikan wawasan yang dapat diterapkan pada seluruh populasi.

Teknik Sampling adalah suatu cara yang ditempuh dengan pengambilan sampel yang benar-benar sesuai dengan keseluruhan obyek penelitian. Teknik pengambilan sampel dalam penelitian ini adalah total sampling. Total sampling adalah teknik pengambilan sampel dimana jumlah sampel sama dengan populasi, Sugiyono $(2005 ; 34)$. Alasan mengambil total sampling karena menurut Sugiyono jumlah populasi yang kurang dari 100 seluruh populasi dijadikan sampel penelitian semuanya.

Dengan teknik penarikan sampel secara Total Sampling maka sampel dalam penelitian ini adalah seluruh populasi yaitu pegawai di Dinas Pemberdayaan Masyarakat dan Desa Kabupaten Asahan. sebanyak 45 orang. Sampel ini tidak termasuk Kepala Dinas dan Peneliti sebagai seorang Kepala Seksi.

Tabel 2. Kerangka Sampel Berdasarkan Jabatan 2021

\begin{tabular}{|r|l|r|r|c|}
\hline No & \multicolumn{1}{|c|}{ Jabatan } & $\begin{array}{r}\text { Jlh } \\
\text { Populasi }\end{array}$ & $\begin{array}{r}\text { Jlh } \\
\text { Sampel }\end{array}$ & Ket \\
\hline 1 & Kepala Dinas & 1 & - & Tidak diteliti \\
\hline 2 & Sekretaris & 1 & 1 & Diteliti \\
\hline 3 & Kepala Bidang & 3 & 3 & Diteliti \\
\hline 4 & Kepala Seksi & 9 & 8 & 1 Tidak Diteliti \\
\hline 5 & Kepala Sub. Bagian & 2 & 2 & Diteliti \\
\hline 6 & $\begin{array}{l}\text { Staf/Jabatan } \\
\text { Fungsional }\end{array}$ & 15 & 15 & Diteliti \\
\hline 7 & $\begin{array}{l}\text { Tenaga SP3/ Tenaga } \\
\text { Sukarela }\end{array}$ & 16 & 16 & Diteliti \\
\hline \multicolumn{2}{|r|}{ Jumlah } & $\mathbf{4 7}$ & $\mathbf{4 5}$ & \\
\hline
\end{tabular}

Sumber: Dinas Pemberdayaan Masyarakat dan Desa Kabupaten Asahan, 2021

1

\section{Hasil Dan Pembahasan Hasil Penelitian \\ 3.1 Uji Validitas Data}


Pengujian validitas instrumen menggunakan Analysis Correlate Bivariate untuk mencari Correlation Coefficient dari Product Moment Pearson dengan SPSS. Kemudian dibandingkan dengan nilai rtable untuk $\alpha=$ 0.05 dengan derajat kebebasan $(\mathrm{dk}=\mathrm{n}-2)$ sehingga didapat rtable. Untuk butir pernyataan dengan nilai koefisien korelasi (rhitung) $>r$ table maka butir pernyataan tersebut dinyatakan valid.

Karena jumlah responden yang digunakan untuk uji validitas sebanyak 45 orang, maka nilai rtabel dapat ditentukan dari: $\mathbf{d k}=\mathbf{n}-\mathbf{2}=\mathbf{4 5}$ $-2=43$.

Nilai $r$ tabel dengan $\mathrm{dk}=43$ adalah 0,294. Oleh karena itu, item pertanyaan dinyatakan valid jika rhitung $>0,294$.

Table 3. Hasil Uji Validitas Variabel Inovasi (X1)

\begin{tabular}{|c|c|c|c|}
\hline Variabel & rhitung & rtabel & Keterangan \\
\hline 1 & 0,614 & 0,294 & Valid \\
\hline 2 & 0,667 & 0,294 & Valid \\
\hline 3 & 0,836 & 0,294 & Valid \\
\hline 4 & 0,851 & 0,294 & Valid \\
\hline 5 & 0,365 & 0,294 & Valid \\
\hline 6 & 0,784 & 0,294 & Valid \\
\hline 7 & 0,648 & 0,294 & Valid \\
\hline 8 & 0,836 & 0,294 & Valid \\
\hline 9 & 0,838 & 0,294 & Valid \\
\hline 10 & 0,667 & 0,294 & \\
\hline
\end{tabular}

Table 4. Hasil Uji Validitas Variabel Perhatian secara rinci (X2)

\begin{tabular}{|c|c|c|c|}
\hline Nomor Soal & rhitung & rtabel & Keterangan \\
\hline 1 & 0,981 & 0,294 & Valid \\
\hline 2 & 0,984 & 0,294 & Valid \\
\hline 3 & 0,930 & 0,294 & Valid \\
\hline 4 & 0,971 & 0,294 & Valid \\
\hline 5 & 0,423 & 0,294 & Valid \\
\hline 6 & 0,712 & 0,294 & Valid \\
\hline 7 & 0,989 & 0,294 & Valid \\
\hline 8 & 0,977 & 0,294 & Valid \\
\hline 9 & 0,987 & 0,294 & Valid \\
\hline 10 & 0,981 & 0,294 & \\
\hline
\end{tabular}

Table 5. Hasil Uji Validitas Variabel Orientasi hasil (X3)

\begin{tabular}{|r|c|c|c|}
\hline Nomor Soal & rhitung & rtabel & Keterangan \\
\hline 1 & 0,650 & 0,294 & Valid \\
\hline 2 & 0,709 & 0,294 & Valid \\
\hline 3 & 0,777 & 0,294 & Valid \\
\hline 4 & 0,786 & 0,294 & Valid \\
\hline 5 & 0,638 & 0,294 & Valid \\
\hline 6 & 0,567 & 0,294 & Valid \\
\hline 7 & 0,539 & 0,294 & Valid \\
\hline 8 & 0,774 & 0,294 & Valid \\
\hline 9 & 0,713 & 0,294 & Valid \\
\hline 10 & 0,682 & 0,294 & Valid \\
\hline
\end{tabular}

Table 6. Hasil Uji Validitas Variabel Kinerja (Y) 


\begin{tabular}{|r|c|c|c|}
\hline Nomor Soal & rhitung & rtabel & Keterangan \\
\hline 1 & 0,732 & 0,294 & Valid \\
\hline 2 & 0,684 & 0,294 & Valid \\
\hline 3 & 0,676 & 0,294 & Valid \\
\hline 4 & 0,732 & 0,294 & Valid \\
\hline 5 & 0,601 & 0,294 & Valid \\
\hline 6 & 0,826 & 0,294 & Valid \\
\hline 7 & 0,857 & 0,294 & Valid \\
\hline 8 & 0,654 & 0,294 & Valid \\
\hline 9 & 0,788 & 0,294 & Valid \\
\hline 10 & 0,732 & 0,294 & \\
\hline
\end{tabular}

Tabulasi data variabel dependen dan independen yang terdapat pada tabel 3 hingga 6 tersebut di atas seluruh pernyataan dalam setiap variabel memiliki nilai Corrected Item Correlation (rhitung) lebih besar dari rtabel. Dengan demikian, dapat dikatakan bahwa setiap butir pernyataan adalah valid sehingga penelitian ini dapat diteruskan dalam pengujian reliabilitas.

\subsection{Uji Reliabilitas Data}

Pada penelitian ini, uji reliabilitas menggunakan metode Cronbach Alpha. Reliabilitas diukur dengan menguji tingkat konsistensi hasil pengukuran jika dilakukan pengukuran ulang. Andal atau tidaknya suatu data dapat dilihat dari koefisien alpha yang dihasilkan, data yang mendekati angka 1 (satu) dapat dikatakan memiliki keandalan tinggi. Nilai koefisien Cronbach Alpha yang mendekati 1 menunjukkan bahwa hasil yang diperolehsemakin konsisten sehingga dikatakan mempunyai reliabilitas yang tinggi. Suatu data dikatakan akurat jika nilai koefisien cronbach alpha minimum adalah 0,60. Uji reliabilitas pada penelitian ini menggunakan program SPSS versi 20.0.

Table 7. Hasil Uji Reabilitas

\begin{tabular}{|r|c|c|c|}
\hline Variable & $\begin{array}{c}\text { Cronbach's } \\
\text { Alpha }\end{array}$ & N of Items & $\begin{array}{c}\text { Reabilitas } \\
\text { Status }\end{array}$ \\
\hline $\mathrm{X} 1$ &, 896 & 10 & Reliabel \\
\hline $\mathrm{X} 2$ &, 960 & 10 & Reliabel \\
\hline $\mathrm{X} 3$ &, 876 & 10 & Reliabel \\
\hline $\mathrm{Y}$ &, 900 & 10 & Reliabel \\
\hline
\end{tabular}

Hasil uji reliabilitas yang dilakukan terhadap variabel dependen dan independen seperti tertera pada tabel $7 \mathrm{di}$ atas, terlihat bahwa nilai Cronbach Alpha seluruh variabel berkisar antara 0 sampai 1 dan lebih cenderung mendekati angka 1. Dengan demikian keseluruhan item dalam instrumen pengukuran dapat kategorikan sangat reliabel.

\subsection{Uji Asumsi Klasik}

\subsubsection{Uji Normalitas Data}

Pengujian normalitas data bertujuan untuk melihat normal tidaknya sebaran data yang akan dianalisis. Model regresi yang baik adalah distribusi normal atau mendekati normal. Untuk melihat normalitas data ini digunakan pendekatan grafik yaitu Normality Probability Plot. Deteksi normalitas dengan melihat penyebaran data (titik) pada sumbu diagonal dari grafik. dasar pengambilan keputusan (Santoso, 2004: 214), adalah:

a. Jika data menyebar disekitar garis diagonal dan mengikuti arah garis diagonal, maka model regresi memenuhi asumsi normalitas.

b. Jika data menyebar jauh dari garis diagonal dan atau tidak mengikuti arah garis diagonal, maka model regresi tidak memenuhi asumsi normalitas.

Pada output SPSS bagian normal P-P Plot of Regresion Standardized Residual, dapat dijelaskan bahwa data-data (titik-titik) 
cenderung lurus mengikuti garis diagonal sehingga data dalam penelitian ini cenderung berdistribusi normal, seperti terlihat pada gambar di bawah ini.

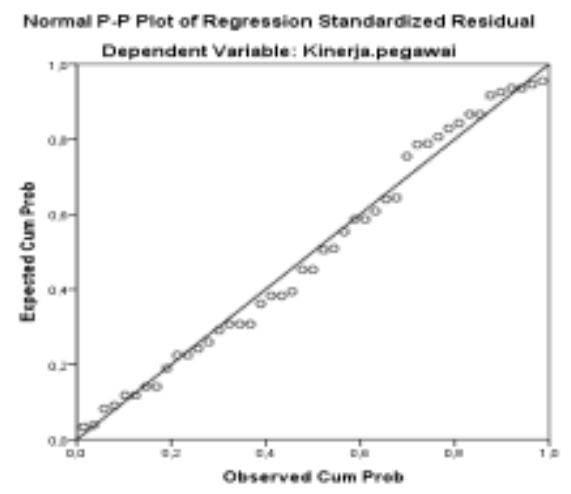

Gambar 5.1. Normalitas Data

\subsubsection{Uji Multikolinearitas}

Pengujian multikolinearitas dilakukan untuk melihat apakah pada model regresi ditemukan adanya korelasi antara variabel bebas. Jika terjadi korelasi, maka dinamakan terdapat problem multikolinearitas. Cara mendeteksinya adalah dengan melihat nilai Variance Inflation Factor (VIF). Menurut Santoso (2014: 203), pada umumnya jika VIF lebih besar dari 5, maka variabel bebas tersebut mempunyai persoalan multikolinearitas dengan variabel bebas lainnya Pada output SPSS bagian Coefficient, semua angka VIF berada di bawah 5, hal ini menunjukan tidak terjadi multikolinearitas, seperti dapat dilihat pada tabel di bawah ini.

Tabel 8 Uji Multikolinearitas

Coefficients
\begin{tabular}{|l|c|c|c|}
\hline \multirow{2}{*}{\multicolumn{2}{|c|}{ Model }} & \multicolumn{2}{c|}{$\begin{array}{r}\text { Collinearity } \\
\text { Statistics }\end{array}$} \\
\cline { 2 - 4 } \multicolumn{2}{c|}{} & Tolerance & VIF \\
\hline \multirow{3}{*}{1} & (Constant) & & \\
\cline { 2 - 4 } 1 & Inovasi & .655 & 1.526 \\
\cline { 2 - 4 } & Perhatian.rinci & .761 & 1.314 \\
\cline { 2 - 4 } & Orientasi.Hasil &, 833 & 1,201 \\
\hline
\end{tabular}
a. Dependent Variable: kinerja.pegawai
Sumber: Out Put SPSS. Data Diolah-2021

\subsubsection{Uji Heteroskedastisitas}

Pengujian heteroskedastisitas bertujuan untuk melihat apakah dalam sebuah model regresi terjadi ketidaksamaan varians dari residual yang merupakan suatu pengamatan ke pengamatan yang lainnya. Jika varians dari residual yang merupakan suatu pengamatan ke pengamatan yang lain bernilai tetap, maka hasil data disebut homoskedastisitas dan jika varians berbeda atau bernilai tidak tetap maka disebut heteroskedastisitas. Model regresi yang baik adalah model yang bernilai tetap atau homoskedastisitas atau tidak terjadi heteroskedastisitas.

Deteksi heteroskedastisitas dilakukan dengan cara melihat ada tidaknya pola tertentu pada data yang diolah. Menurut Santoso (2014: 208), dasar pengambilan keputusannya adalah:

a. Jika pola tertentu seperti titik-titik yang ada membentuk suatu pola tertentu yang teratur, maka terdapat situasi heteroskedastisitas.

b. Jika tidak ada pola yang jelas, serta titiktitik menyebar di atas dan di bawah angka nol pada sumbu Y, maka tidak terjadi heteroskedastisitas. Pada output SPSS dibagian Scatrerplot, terlihat titk-titik menyebar secara

acak, tidak membentuk sebuah pola tertentu yang jelas, serta tersebar baik di atas maupun di bawah angka nol pada sumbu Y. Hal ini berarti tidak terjadi heterskedastisitas pada model regresi, sehingga model regresi layak dipakai. Pola Scatterplot dapat dilihat pada gambar di bawah ini.

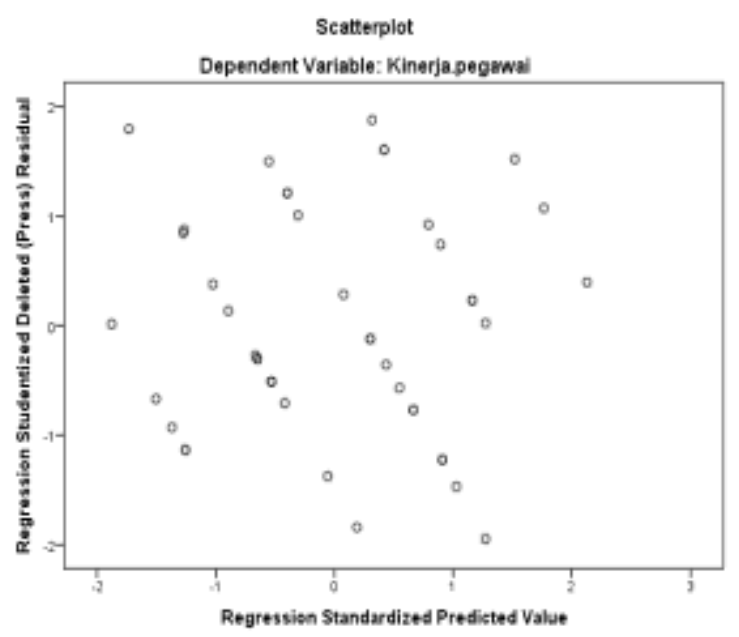

Gambar 2. Uji Heteroskedastitas

\section{Evaluasi Data \\ 4.1 Pengujian Hipotesis}

Dalam evaluasi data ini penulis akan melakukan pengujian hipotesis, baik secara partial ataupun secara simultan. Selanjutnya untuk mempermudah dalam evaluasi data ini, maka penulis mencari niali-nilai yang dibutuhkan dengan menggunakan perangkat lunak komputer yaitu program SPSS V.20.00 for windows dengan hasil data sebagai berikut: 
Tabel 9. Hasil Uji Statistik Keofesien Regresi

Coefficients ${ }^{\mathrm{a}}$

\begin{tabular}{|c|c|c|c|c|c|c|}
\hline \multirow{2}{*}{\multicolumn{2}{|c|}{ Model }} & \multicolumn{2}{|c|}{$\begin{array}{l}\text { Unstandardized } \\
\text { Coefficients }\end{array}$} & \multirow{2}{*}{$\begin{array}{c}\begin{array}{r}\text { Standardized } \\
\text { Coefficients }\end{array} \\
\text { Beta } \\
\end{array}$} & \multirow[t]{2}{*}{$\mathrm{t}$} & \multirow[t]{2}{*}{ Sig. } \\
\hline & & B & Std. Error & & & \\
\hline \multirow{4}{*}{1} & (Constant) & ,660 & 4,135 & & ,160 & ,874 \\
\hline & Inovasi & .234 & .062 & 353 & 3,795 & .000 \\
\hline & Perhatian.rinci & .345 & .082 & .361 & 4.188 & .000 \\
\hline & Orientasi.Hasil & .452 & .083 & .448 & 5.435 & .000 \\
\hline
\end{tabular}

a. Dependent Variable: kinerja.pegawai

Sumber: Out Put SPSS Data Diolah-2021

Dari tabel 9 di atas dapat dibuat persamaan regresi sebagai berikut:

$\mathrm{Y}=4,135+0,234 \mathrm{X} 1+0,345 \times 2+0,452 X 3+$ $\varepsilon$.

Dari persamaan tersebut dijelaskan bahwa koefesien X1 (Inovasi) mempunyai nilai positif yaitu 0,234 . Hal ini menunjukan bahwa variabel Inovasi mempunyai pengaruh positif terhadap variabel Kinerja Pegawai. Koefesien $\mathrm{X} 2$ (Perhatian secara rinci) memiliki nilai positif yaitu 0,345 . Hal ini menunjukan bahwa variabel Perhatian secara rinci mempunyai pengaruh positif terhadap variabel Kinerja
Pegawai. Koefesien X3 (Orientasi hasil) juga memiliki nilai positif yaitu 0,452 . Hal ini menunjukan bahwa variabel Orientasi hasil juga mempunyai pengaruh positif terhadap varibel Kinerja Pegawai.

\subsection{Pengujian Secara Simultan (Uji F)}

Hasil pengujian hipotesis secara simultan antara Inovasi, Perhatian secara rinci dan Orientasi hasil terhadap Kinerja Pegawai di Dinas Pemberdayaan Masyarakat dan Desa Kabupaten Asahan dapat dilihat pada tabel di bawah ini.

Tabel 10. Hasil Uji Statistik Secara Simultan

ANOVA ${ }^{a}$

\begin{tabular}{|l|l|r|r|l|r|r|}
\hline \multicolumn{2}{|l|}{ Model } & Sum of Squares & df & Mean Square & \multicolumn{1}{c|}{ F } & Sig. \\
\hline \multirow{3}{*}{1} & Regression & 39,758 & 3 & 13,253 & 45,204 & nnob \\
\cline { 2 - 7 } & Residual & 12,020 & 41 &, 293 & & \\
\cline { 2 - 7 } & Total & 51,778 & 44 & & & \\
\hline
\end{tabular}

a. Dependent Variable: Kinerja.pegawai

b. Predictors: (Constant), Orientasi.Hasil, Perhatian.rinci, Inovasi

Dari tabel 10 di atas dapat diketahui denngan jelas bahwa nilai Fhitung adalah 45,204 dan nilai signifikansi 0,000. Diketahui nilai Ftabel dengan tingkat kepercayaan $95 \%(\alpha: 0,05)$ adalah 2.840. Oleh karena itu nilai Fhitung> Ftabel (45,204 > 2,840 maka Ho ditolak dan menerima hipotesis dalam penelitian ini yaitu bahwa Inovasi,, Perhatian secara rinci, dan Orientasi hasil berpengaruh positif dan signifikan terhadap Kinerja Pegawai di Dinas Pemberdayaan Masyarakat dan Desa Kabupaten Asahan.

\subsection{Pengujian Secara Parsial (Uji t)}

Tabel 11 Hasil Uji Parsial Variabel X Terhadap Y

\section{Coefficients ${ }^{a}$}

\begin{tabular}{|c|c|c|c|c|c|}
\hline \multirow[t]{2}{*}{ Model } & \multicolumn{2}{|c|}{$\begin{array}{c}\text { Unstandardized } \\
\text { Coefficients }\end{array}$} & \multirow{2}{*}{$\begin{array}{c}\text { Standardized } \\
\text { Coefficients } \\
\text { Beta }\end{array}$} & \multirow[t]{2}{*}{$\mathrm{t}$} & \multirow[t]{2}{*}{ Sig. } \\
\hline & $\mathrm{B}$ & Std. Error & & & \\
\hline \multirow{4}{*}{\begin{tabular}{|l|l}
1. & (Constant) \\
Inovasi Perhatian.rinci \\
Orientasi.Hasil
\end{tabular}} & ,660 & 4,135 & & , 160 & ,874 \\
\hline & 234 & ,062 & ,353 & 3,795 & 000 \\
\hline &, 345 & ,082 & ,361 & 4,188 &, 000 \\
\hline &, 452 &, 083 & 448 & 5,435 & 000 \\
\hline
\end{tabular}




\subsection{Pengaruh $X 1$ terhadap $Y$}

Secara parsial pengaruh Inovasi(X1) terhadap Kinerja Pegawai (Y) dapat diketahui dengan memperhatikan data pada tabel 5.14 di atas. Berdasarkan tabel tersebut diperoleh nilai thitung sebesar 3,795 dan nilai signifikansi $\quad 0,000$. Sedangkan nilai tabel pada tingkat kepercayaan 95\% $(\alpha: 0,05)$ adalah 2,021 . Oleh karena itu nilai thitung $>$ ttabel $(3,795>2,021)$ maka $\mathrm{H}_{\mathrm{O}}$ ditolak dan menerima hipotesis dalam penelitian ini yaitu variabel Inovasi berpengaruh positif terhadap Kinerja Pegawai di Dinas Pemberdayaan Masyarakat dan Desa Kabupaten Asahan.

\subsection{Pengaruh $X 2$ terhadap $Y$}

Secara parsial pengaruh Perhatian secara rinci (X2) terhadap Kinerja Pegawai (Y) dapat dilihat pada tabel 5.14 di atas. Berdasarkan tabel tersebut diperoleh nilai thitung sebesar 24,188 dan nilai signifikansi 0,000 . Sedangkan nilai ttabel pada tingkat kepercayaan $95 \%(\alpha$ : $0,05)$ adalah 2,021. Oleh karena itu nilai thitung > tabel $(4,188>2,021)$ maka $\mathrm{H}_{\mathrm{O}}$ ditolak dan menerima hipotesis dalam penelitian ini yaitu Perhatian secara rinci berpengaruh positif terhadap Kinerja Pegawai di
Dinas Pemberdayaan Masyarakat dan Desa Kabupaten Asahan.

\subsection{Pengaruh $X 3$ terhadap $Y$}

Untuk mengetahui secara parsial pengaruh orientasi hasil (X3) terhadap Kinerja Pegawai (Y) dapat dilihat pada tebel 5.14 di atas. Berdasarkan tabel tersebut diperoleh nilai thitung sebesar 5,435 dan nilai signifikansi $\quad 0,000$. Sedangkan nilai ttabel pada tingkat kepercayaan 95\% ( $\alpha: 0,05)$ adalah 2,021 . Oleh karena itu nilai thitung > ttabel $(5,435>2,021)$ maka $\mathrm{Ho}_{\mathrm{o}}$ ditolak dan menerima hipotesis dalam penelitian ini yaitu variabel Orientasi hasil berpengaruh positif terhadap Kinerja Pegawai di Dinas Pemberdayaan Masyarakat dan Desa Kabupaten Asahan.

\subsection{Uji Koefisien Determinasi $\left(\mathbf{R}^{2}\right)$}

Uji determinan digunakan untuk mengetahui seberapa besar pengaruh variabel independent terhadap variabel dependent. Untuk melihat hasil uji determinan maka dapat diketahui nilai $\mathrm{R}$ Square atau koefesien determinasi dapat dilihat di bawah ini.

Tabel 12 Model Summary

Model Summaryb

\begin{tabular}{l|r|r|r|r|r|r|}
\hline Model & $\mathrm{R}$ & $\mathrm{R}$ Square & \multicolumn{1}{c|}{$\begin{array}{c}\text { Adjusted R } \\
\text { quare }\end{array}$} & $\begin{array}{c}\text { Std. Error of } \\
\text { the Estimate }\end{array}$ & \multicolumn{2}{|c|}{ Change Statistics } \\
\cline { 5 - 7 } & & & & $\begin{array}{l}\text { R Square } \\
\text { Change }\end{array}$ & F Change \\
\hline 1 &, $876 \mathrm{a}$ &, 768 &, 751 &, 54145 &, 768 & 45,204 \\
\hline
\end{tabular}
$\begin{aligned} & \text { a. Predictors: (Constant), Orientasi.Hasil, Perhatian.rinci, Inovasi } \\
& \text { b. Dependent Variable: Kinerja.pegawai }\end{aligned}$

Pada tabel di atas dapat diketahui bahwa Nilai R Square adalah 0,768. Hal ini menunjukan bahwa 76,80\% variabel Kinerja Pegawai di Dinas Pemberdayaan Masyarakat dan Desa Kabupaten Asahan dapat dijelaskan oleh variabel Inovasi, Perhatian secara rinci dan Orientasi hasil sedangkan sisanya sebesar $23,20 \%$ tidak dilakukan penelitian.

\section{Kesimpulan}

Dari hasil uji yang dilakukan dapat disimpulkan bahwa:

1. Variabel inovasi memiliki nilai thitung sebesar 3,759 dan signifikansi 0,000 . Variabel perhatian secara rinci memiliki nilai thitung sebesar 4,188 dan signifikansi 0,000 dan variabel orientasi hasil memiliki nilai thitung sebesar 5,435 dan signifikansi 0,000 . Dengan demikian variabel Inovasi, Perhatian secara rinci dan Orientasi hasil secara parsial atau sendiri-sendiri berpengaruh positif dan signifikan terhadap Kinerja pegawai di Dinas Pemberdayaan Masyarakat dan Desa Kabupaten Asahan.

2. Pengujian yang dilakukan terhadap variabel Inovasi, Perhatian secara rinci dan Orientasi hasil secara bersama-sama atau simultan berpengaruh positif dan signifikan terhadap Kinerja pegawai di Dinas Pemberdayaan Masyarakat dan Desa Kabupaten Asahan dengan nilai sebesar 45,204 dan signifikansi level 0,000 .

3. Nilai $\mathrm{R}$ Square adalah 0,768. Hal ini menunjukan bahwa 76,80\% variabel Kinerja 
Pegawai di Dinas Pemberdayaan Masyarakat dan Desa Kabupaten Asahan dapat dijelaskan oleh variabel Inovasi, Perhatian secara rinci dan Orientasi hasil sedangkan sisanya sebesar $23,20 \%$ tidak dilakukan penelitian.

\section{DAFTAR PUSTAKA}

Achmad., dkk. 2010. Manajemen Administrasi. Jakarta : UI Press.

Bastian, Indra. 2007. Sistem Akuntansi Sektor Publik. Buku 1, Edisi 2. Jakarta: Penerbit Salemba Empat

Donnelly, J.H., Gibson. James L. and Ivancevich, John. 1994. Fundamental of Management. Texas: Business Publication.

Fatmah Bagis, Bima Cinintya Pratama dan Alfato Yusnar Kharismasyah. 2019.

Pengaruh Disiplin Kerja, Komitmen Organisasi dan Kepuasan Kerja terhadap Kinerja Karyawan Studi Kasus Institusi Pendidikan.

https://fe.ummetro.ac.id/ejournal/index.php/J M/article/view/394.

Gibson. L \& Ivancevich. 2001. Organizations (Behavior, Structure and Process), Richard D. Irwin, Inc.terjemahan. Jakarta: Binarupa aksara.

Greenberg, Jerald dan Robert A. Baron. 2003. Behaviour in Organizations, Understanding and Managing The Human Side of Work. Third Edition. Massachuscets: Allinand Bacon.

Griffin, R.W. 2002. Management. Second Edition. Boston: Houhton Mifflin Press.

Hasibuan, Malayu. 2014. Manajemen Sumber Daya Manusia. Jakarta: Bumi Aksara.

Istijanto. 2006. Riset Sumber Daya Manusia. Jakarta: Gramedia Pustaka Utama. Kreitner, Robert. 2008. Perilaku Organisasi. Jakarta: Salemba Empat.

Lenny Apriyanti dan Aan Khurosani. 2018. Analisis Disiplin Kerja dan Budaya Organisasi Terhadap Kinerja Karyawan, Serta Komitmen Organisasi Sebagai Variabel Intervening (Studi Empirik Karyawan Bank BTN Cabang Cilegon, Banten).

https://jurnal.untirta.ac.id/index.php/JRBM/a rticle/view/9355.

Lukman, Hakim. 2015. Karakteristik Budaya Organisasi Kuat sebagai Upaya Meningkatkan Kinerja Industri di Batik Danar Hadi Surakarta. http://journals.ums.ac.id/index.php/benefit/ar ticle/view/2320.

Mangkunegaran, AA. Anwar Prabu. 2005. Manajemen Sumber Daya Manusia Perusahaan. Remaja Rosdakarya. Bandung

Mathis, R.L. \& Jackson, J.H. 2002. Human

Resources Management. Jakarta: Salemba Empat.

McShane, Steven, M. Von Glinow. 2008. Organizational Behavior, Edition 5 . Chicago: McGraw Hill.

Mondy, R.W., Noe, R.M., Premeaux, S.R. 1993. Human Resource Management (3rded.). Massachusetts: Allyn and Bacon.

Munandar, A.S. 2001. Psikologi Industri dan Organisasi. Jakarta: UI. Chaplin, Notoatmodjo, Soekidjo. 2009. Pengembangan Sumber Daya Manusia. Jakarta: Rineka Cipta

Porter, Michael E. 2008. Competitive Advantage: Creating and Sustaining Superior Performance. New York Free Press.

Prawirosentono, Suyadi. 1999. Kebijakan Kinerja Karyawan. Yogyakarta: BPFE.

Robbins, Stephen P. dan Timothy A. Judge.2014. Perilaku Organisasi. Edisi 16. Jakarta: Salemba Empat

Safari, T. 2004. Kepemimpinan. Edisi Pertama. Yogyakarta: Graha Ilmu

Santi Santi dan Muhammad Basyir. 2020. Pengaruh Budaya Organisasi Dan Disiplin Kerja Terhadap Motivasi Kerja Serta Dampaknya terhadap Komitmen Organisasi pada Pegawai Dinas Keuangan Kabupaten Gayo Lues. http://www.jim.unsyiah.ac.id/EMGL/article/ view/15505.

Siagian, Sondang. P. 2004. Manajemen Sumber Daya Manusia. Jakarta: Rineka Cipta.

Simanjuntak, Payaman J. 2005. Manajemen dan. Evaluasi Kinerja. Jakarta: FE UI

Stolovitch, Harold D., and Keeps, Erica J. 1992. Handbook of Human Performance Technology A Comprehensive Guide for Analysis and Solving Performance Problem in Organizations. San Francisco: Jersey

Sugiyono. 2017. Metode Penelitian Administrasi. Bandung: Alfabeta.

Thoha, Miftah. 2014. Budaya Organisasi. Jakarta; PT. Raja Grafindo Persada. Tika, Moh. Pabundu. 2008. Metodologi Riset Bisnis. PT Bumi Aksara.Jakarta Umar. 
2010. Riset SDM dalam Organisasi. Jakarta: Gramedia Pustaka.

Veithzal, Rivai. 2014. Manajemen Sumber Daya Manusia untuk Perusahaan. Jakarta: Raja Grafido Persada.

Wagiman S dan Himawan Arif Sutanto. 2018. Pengaruh Budaya Organisasi, Komitmen Organisasidan Kepuasan Kerja terhadap Kinerja Karyawan (Studi pada PT. Bank Rakyat Indonesia (Persero) Tbk.Kantor Wilayah Semarang). https://www.unisbank.ac.id/ojs/index.php/se ndi_u/article/view/6036.

William N. Dunn. 2006 Analisis Kebijakan Publik. Yogjakarta: Gadjah Mada University Press.

Williams, Edwin Bucher. 1977. The Scriber-Bantam English Dictionary. Michigan: Scribner. 